wind soon quieted over the area but hail continued to fall incessantly until $6: 40$ p.m.

The area covered by the hail was elongated, about 9 miles northeast to southwest and 6 miles across at the widest. Selden was located a little to the northeast of the center of the area.

In addition, to the hail, rain was variously estimated at 3 to 5 inches, and many basements were flooded.

The hail accumulated to a depth of 18 inches and was mostly pea or marble size and many of the stones were soft. Drifts wero 3 to 4 feet deep at the sides of buildings where it fell from the roofs. Piles along the streets and roads remained for 2 days. Traflic on U.S. Highway $S 3$ was halted, and approximately 100 automobiles were stalled 4 hours, or more, until bulldozers could open the roads. Snow plows were unable to move the weight.

The Red Cross reported 2 business buildings destroyed, major damage done to 10 business houses, 8 farm buildings, and 5 homes. Minor damage was indieated to almost every building in the aren, 154 homes, 125 farm buildings, and 27 business buildings. In some measure the damage was due to the continuous pelting of the stones but the greater losses resulted from the tremendous weight of accumulated hail on flat- or nearly flat-roofed buildings, causing them to collapse. The hail accumulation on a truck scale, $10 \times 45$ feet, weighed 28,000 pounds, or 62.2 pounds per square foot. Damage over the area was estimated at $\$ 500,000$.

Trees were stripped of leaves and small branches, and with the ground hail-corered the town had much the appearance of winter. In just a few minutes the temperature on local thermometers dropped from near $80^{\circ}$ to $38^{\circ}$ during the storm.

There were several narrow escapes as roofs collapsed, especially in the restaurant, where a number of people had collected, but only one man was slightly injured when struck on the head as an awning gave way due to the weight of the hail. Two men caught in a pickup truck were unible to shout loud enough for the other to hear above the roar of the hail on the metal cab roof.

$\Lambda$ local citizen described the storm as follows, "The hail began and just didn't stop."

A news writer expressed his reaction to the scene quite well in these words, "I saw a chunk of January in the heart of June."

\title{
WORLD RECORD ONE-MINUTE RAINFALL AT UNIONVILLE, MARYLAND
}

\author{
HOWARD H. ENGELBRECHT \\ U.S. Weather Bureau, Baltimore, Md. \\ and \\ G. N. BRANCATO \\ U.S. Weather Bureau, St. Louis, Mo. \\ [Manuscript received October 14, 1958; revised August 10, 1959]
}

On July 4, 1956, 1.23 inches of rain apparently fell in one minute at Unionville, Md. During the afternoon intense thunderstorms prevailed in the Piedmont area over northern Virginia and adjacent portions of north central Maryland. Unusual instability and intense storm development was further evidenced by a report of a fumel cloud near Quantico, Va.

At a U.S. Geological Survey stream gaging station, Little Pipe Creek at $\Lambda$ vondale, about 10 miles northwest. of Unionville, Md., streamflow reached the greatest peak flow for this station since it, was established in August 1947. Further, based on an analysis of the annual extreme peak discharges, the $\mathrm{July} 4,1956$ penk discharge is estimated to have a return period of more than 20 years. At Westminster, 12 miles northeast of Unionville, severe thunderstorms brought the heaviest rainstorm in years. Streets resembled rivers, and many basements were flooded with several inches of water. Telephone communications were put out of order by the heavy rains, and fields were badly eroded. Gardens were flooded with damage to regetables, and the local hay crops were flattened in the fields.

Associated with this area of heary storms was the cloudburst reported at Unionville, Md. during which 1.23 inches of precipitation occurred in an estimated period of 1 minute. The total precipitation in the Unionville storm was 3.60 inches for the period from $1450 \mathrm{EST}$ to $2330 \mathrm{EST}$ with a total of $2.8+$ inches occurring during the 50 -minute period from 1450 to $1540 \mathrm{Es}$. Many basements in Unionville were flooded; at least one was filled to the ground level or higher. Residents reported only one severe bolt of lightning and one loud crash of thunder but little or no wind during the storm. The sky became so dark that residents had to switch on electric lights. Mr. G. P. Von Eiff, cooperative weather observer, was in Frederick, Md. at the time of the storm and reported that clouds in the direction of Unionville were intensely dark. The wife of the cooperative weather observer reported rainfall 


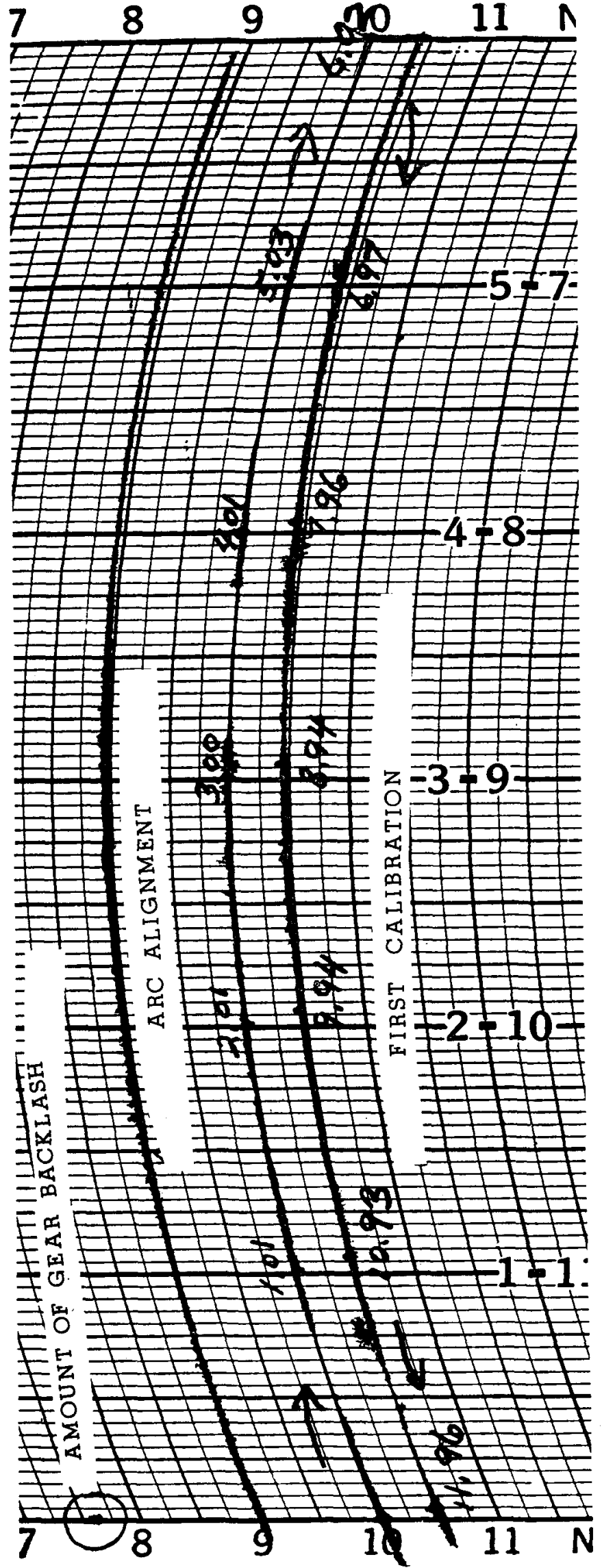

FIGURE 1.-Portion of recording rain gage chart (WB Form 1028C) used on July 11, 1956, in calibration and are alignment checks of recording rain gage at Unionville, Md.

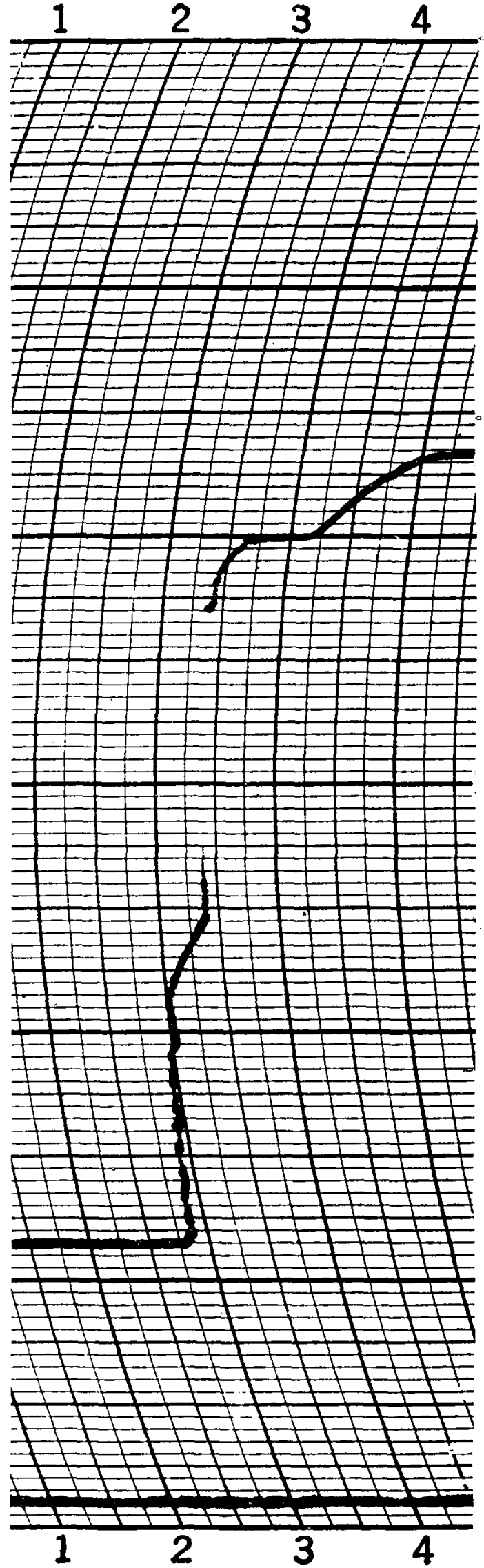

Fraure 2.-Portion of recording rain gage chart (WB Form 1028C) showing trace of the world-record 1-minute rainfall at Unionville, Md., July 4, 1956. 
so heavy that new gutters and downspouts installed on a warehouse were almost useless as water poured off the roof like the "Niagara Falls". The Unionville rainstorm was reported as the worst since May 21, 1942 when a total of 2.90 inches of rain occurred in one hour from 1800 to 1900 EST and a total of 4.80 inches for the 24 -hour period ending at 1700 esT May 22, 1942 as reported by Mr. Von Eiff.

The 1.23-inches-in-1-minute rainfall was measured with a recording rain gage. The gage, a Friez Universal Type, 12-inch capacity, dual traverse pen, and 24-hour clock gear with WB Form 1028C on chart drum, is located in a satisfactory exposure. A few low trees grow near the gage to the southwest but do not interfere with the exposure. The station is near the bank of a creek which drains a small watershed. Taller trees and buildings generally surround the station area at a distance of 75 to 100 feet or more and provide an exposure more or less sheltered from strong winds.

The following points which could have contributed to an error were considered in evaluating this record: 1 . Can a 1-minute time interval be measured on chart WB Form $1028 \mathrm{C}$ ? 2. Was the clock operating properly? 3. Could the clock have stopped momentarily and then started again? 4. Was the clock taking up backlash during this period? 5. Could a bug have gotten in the clock gears and briefly stopped or delayed forward motion? 6. Could the pen have stuck momentarily on the chart? 7. Could a leaf or other object have closed the opening in the receiver until a buildup of water forced it through the opening? 8. Was the gage in proper calibration for scale and for arc? 9. Was there any defect in the linkage or bearings of the gage mechanism which might account for the pen failing to rise properly during the period of heavy precipitation? 10. Was the chart seated properly on the flange of the clock drum? 11. Could the chart have expanded due to dampness or high relative humidity? 12 . Was the clock properly seated on the spindle and completely at the lowest point? 13. Could a gust of wind have jolted the gage and clock to give the gears backlash ?

There are, no doubt, other sources for error which might have been considered. However, in order to make some attempt to evaluate the record in the light of the items listed above, the State Climatologist (one of the authors: H. H. E.) and Thomas E. Hostrander, Substation Inspector, made a trip to Unionville late on the 6th to make a preliminary survey of conditions before the memory of residents had dimmed and water marks and the condition of the rain gage had a chance to change appreciably. The gage was checked by pouring in a measured quantity of water. No error in calibration was noted. Standard weights were not available at the U.S. Weather Bureau, Baltimore, Md., as the inspector's truck was in a garage in a nearby city. The gage was found to be in generally good condition; however, it was noted that the flood waters had risen and flooded the recording rain gage up to the 0.90 -inch level of the chart. The clock had stopped at 2330 EsT July 4, 1956 according to the chart. This may have been due to the effect of the water rising in the clock mechanism. The record rainfall, however, had occurred well before the flood water had come up into the gage. From the appearance of the chart and the time marks on the chart, the clock was operating on time. There was no reason to suppose that it had stopped during the period of heavy rain. The observer, who was out of town during the rainstorm, estimated that he returned to Unionville at $1955 \mathrm{EST}$; he checked the gage and made a time check mark at about 2003 EST.

On July 11, 1956 the Substation Inspector visited the station again and performed a more thorough inspection of the recording rain gage as well as a complete calibration and check for arc alignment. $\mathbf{A}$ calibration using standard weights indicated that the gage was registering correctly between chart scale amounts of 2.00 and 4.00 inches. A check for arc alignment revealed in the traverse from the zero line to the 6-inch line a time regression of about 6 minutes, or an average of 1 minute per 1 inch on the precipitation scale (fig. 1). The pen trace on the chart for the "1-minute" intensity was rather faint but seemed to regress very slightly with respect to the arc lines of the chart, based on a careful inspection through a magnifying glass (fig. 2). This was interpreted as slight forward motion, estimated at not over 1 minute. From the character of the pen trace during the "1-minute period" it did not seem likely that the pen had stuck to the chart. During the checking and calibration routine, however, the Substation Inspector reported that the pen had stuck on the chart. An inspection of the chart used for checking indicates a fuzzy or scratchy pen trace which was not evident on the record chart. The character of the pen trace on a specimen of chart where the pen had stuck appeared as an ink-soaked spot at the place where the pen stuck followed by a blank space and then another spot-type mark again where it stopped. It is doubtful if this check proved anything.

The inspector poured measured quantities of water into the gage at given time intervals of 30 seconds, 1 minute, $1 \frac{1}{2}$ minutes, and 2 minutes. The faint character of the pen trace during the "1-minute rainfall" resembles the pen trace for the simulated 30-second and 1-minute periods in which 1.24 inches of water was poured into the gage. The slope of the are for the "1-minute rainfall" resembles the test ares for 30 seconds or 1 minute and 1.24 inches of water. Of course, this does not prove that a piece of lint or other foreign material did not cause ink to flow more from one side of the pen at one point in the traverse as compared with some other point.

In order to make a more precise evaluation of the record a photograph of the chart was enlarged to a scale in which 1 inch of precipitation on the chart scale equals 2.98 linear inches and 1 hour of chart time equals 1.45 linear inches. A careful measurement with a magnifying glass and engi- 
neer's scale on the enlarged print of the chart revealed that at chart time of $3: 23+(1523$ EST) the pen was at 2.47 inches on the chart scale; at chart time $3: 23-$ (1523 EST) the pen was at 3.70 inches. Based on a regression of 1 minute per inch of precipitation on the chart scale but no correction in calibration of the precipitation scale between 2.00 inches and 4.00 inches it is concluded that 1.23 inches of precipitation occurred in an estimated period of 1 minute or less. 'See figures 1 and 2.

A 1-minute intensity of 1.23 inches exceeds the intensity of 0.69 inch in 1 minute reported for Jefferson, Iowa [1]. Further, the Unionville record 1-minute rainfall does not appear to be incompatible with an extrapolated envelope curve on Jenning's [2] graph of world's greatest observed rainfalls. There is insufficient evidence to indicate that the possible sources of error operated to make the estimated amount erroneous. These same factors were at least as important and at least as difficult to evaluate in other reports of 1-minute intensities. Consequently, the Weather Bureau has accepted the 1.23 inches as a new United States record for a 1-minute period, which also makes it a new world record.

\section{REFERENCES}

1. O. R. Elford, "A New One-Minute Rainfall Record," Monthly Weather Review, vol. 84, No. 2, Feb. 1956, pp. 51-52.

2. Arthur H. Jennings, "World's Greatest Observed Point Rainfalls," Monthly Weather Review, vol. 78, No. 1, Jan. 1950, pp. 4-5. 